\title{
Alternative Dispute Resolution Mechanisms in Colombia and Russia: Conciliation and Mediation
}

\author{
Mecanismos Alternativos de Solución de Conflictos en Colombia \\ y en Rusia: La Conciliación y la Mediación
}

\author{
(iD) \\ Milton Arrieta López \\ Universidad de la Costa, Colombia \\ miltonarrieta@yahoo.com \\ Ilya Vladimirovich Afanasiev \\ Financial University under the Government of the Russian \\ ivafanasev@fa.ru \\ (iD) \\ Abel Meza Godoy \\ Universidad de la Costa, Colombia \\ abelrmg@yahoo.es \\ (iD) \\ Vladimir Dmitriyevich Sekerin \\ Moscow Polytechnic University \\ bcintermarket@yandex.ru
}

\author{
(iD) \\ Sara Noli \\ Universidad del Norte, Colombia \\ saranoli@hotmail.it \\ Recibido: 10 de mayo de 2021 / Aceptado: 09 de septiembre de 2021 \\ https://doi.org/10.17081/just.26.40.4773
}

\begin{abstract}
In this article, the authors compare alternative conflict resolution mechanisms in Colombia and Russia. In the former, conciliation is the most developed alternative dispute resolution mechanism, while in the latter, mediation is the most developed. In order to deepen this comparison, a qualitative research of interpretative nature has been developed with the support of bibliographic-documentary material. The main conclusion is that access to justice is a human right that has been positivized as a fundamental right in the constitutions of both Colombia and Russia. However, the Colombian Constitution allows individuals to exercise their jurisdictional functions on a temporary basis, unlike the Russian Constitution, which only authorizes judges from the Federation to exercise their jurisdictional functions. While conciliation in Colombia is developed and implemented through State-supervised Conciliation and Arbitration Centers, mediation in Russia is in its initial phase and has gradually gained acceptance in society. In both states, the implementation of alternative dispute resolution mechanisms has been driven by the need to decongest the courts and tribunals of ordinary justice. Therefore, it is useful to insist on the massive use of these instruments to make possible a justice that comes from the parties in conflict, that can repair the relations of the subjects in dispute and that tends towards the construction of more peaceful societies.
\end{abstract}

KEY WORDS: ADR, conciliation, mediation, jurisdiction. 


\section{Resumen}

En este artículo, los autores comparan los mecanismos alternos de resolución de conflictos en Colombia y Rusia. En el primero, la conciliación es el mecanismo alternativo de solución de controversias más desarrollado, mientras que en el segundo es la mediación. Para profundizar en esta comparación, se ha desarrollado una investigación cualitativa de corte interpretativo y con apoyo de material bibliográficodocumental. Se concluye principalmente que el acceso a la justicia es un derecho humano que ha sido positivizado como derecho fundamental en las constituciones de Colombia y de Rusia. No obstante, la Constitución de Colombia posibilita la función jurisdiccional a particulares de manera transitoria, a diferencia de la Constitución Rusa, que solo faculta la función jurisdiccional a jueces de la Federación. Mientras que la conciliación en Colombia se encuentra desarrollada e implementada a través de Centros de Conciliación y Arbitraje vigilados por el Estado, la mediación en Rusia se encuentra en fase inicial y ha tenido una aceptación gradual en la sociedad. En ambos Estados la implementación de los mecanismos alternativos de solución de controversias ha obedecido a la necesidad de descongestionar los juzgados y tribunales de justicia ordinaria. Por tanto, resulta útil insistir en la masificación del uso de estos instrumentos para posibilitar una justicia que devenga de las partes en conflicto, que pueda reparar las relaciones de los sujetos en controversia y que propenda por la construcción de una sociedad más pacífica.

PALABRAS CLAVE: MASC, conciliación, mediación, jurisdicción.

Como Citar: Arrieta López, M., Meza Godoy, A., Afanasiev, I. V., Sekerin, V. D., \& Noli, S. (2021). Mecanismos Alternativos de Solución de Conflictos en Colombia y en Rusia: La Conciliación y la Mediación. Justicia, 26(40), 128-142. https://doi.org/10.17081/ just.26.40.4773

\section{Introduction}

The very nature of the conflict implies its inevitability. Conflict is unavoidable and it will always be present in the lives of human beings in multiple dimensions - institutional, social, political, cultural or economic - and at different levels - interpersonal, communitarian and international, considering the impact of globalization in today's societies (Brandt, 2017). Globalization is not a natural process. In other words, it does not comprise events rooted in immutable laws of the economy. Globalization, in large part, derives from a social construction produced by global and individual human determinations (Arrieta, 2020). The impact of conflict transformation methods then goes beyond the merely interpersonal, local or communitybased and can become universal. Therefore, it is possible to say that the sum of peaceful societies could build a global village at peace and suitable for development in its multiple dimensions and levels (Noli et al., 2018). As Bonta (1996) states, peacefully resolved conflicts tend to build more just and developmentfriendly communities.

The Universal Declaration of Human Rights states that "everyone is entitled in full equality to a fair and public hearing by an independent and impartial tribunal, in the determination of his rights and obligations and of any criminal charge against him" (UN General Assembly, 1948, art. 3). From the above, it can be seen that access to justice is a subjective human right that gives people the right to resolve their problems with the participation of the State. Although contemporary theories of philosophy of law present different assumptions for defining and grounding the nature of human rights (Meléndez et al., 2018), the iusnaturalist argument is undoubtedly quite convincing when it bases its principles on consubstantiality of human nature. In other words, human rights derive from the very nature of the human being, since these natural rights are composed of principles of justice with an objective existence prior to that of any positive law and are characterized by the features of unity, universality and immutability. 
Nevertheless, iusnaturalism has also been questioned since not all iusnaturalistic conceptions support the nature and existence of these rights. Only the tradition of iusnaturalistic rationalism of authors such as H. Grotius, S. Pufendorf, B. Spinoza or Ch. Wolff allows for such a possibility. It should also be mentioned that one of the most important problems presented by iusnaturalism is precisely the knowledge and determination of a supposed objective, unitary and universal natural right, since throughout history the same iusnaturalist authors have granted different and often contradictory contents. On the other hand, for ethical constructivism, human rights are based on human rationality, which, in turn, constructs moral rights and obligations. Human rationality would suggest sufficient arguments to justify human rights, so that there is a permanent commitment to reflection and rational argumentation that impacts the moral discourse (Arrieta, 2018; Arrieta, 2019). A contemporary definition of human rights would imply that they emanate from the attributes of the personality of human beings and that the objective right grants them powers, prerogatives and freedoms of a civil, political, economic, social and cultural nature.

The Universal Declaration of Human Rights has been incorporated into the domestic legal systems of Colombia and Russia. In this regard, the Political Constitution of Colombia protected access to justice as a right of individuals within the jurisdictional function of the State in its articles 228 and 229. Furthermore, this function is not exclusive to the judges of the Republic, as the Constitutional Court mentioned in Judgment C-1195 of 2001, when it stated:

\begin{abstract}
According to the jurisprudence of this Corporation, the right to access to justice has a multiple meaning. It includes, inter alia, the availability of adequate and effective procedures for the legal determination of rights and obligations, the resolution of disputes within a reasonable time frame and without undue delay, the adoption of decisions with full respect for due process, the existence of a comprehensive and adequate set of mechanisms for the settlement of disputes, the provision of mechanisms to facilitate access to justice by the poor, and the provision of justice to enable access to justice throughout the national territory. This right is also guaranteed through the use of alternative dispute resolution mechanisms (Colombian Constitutional Court, Full Chamber, D-3519 - C-1195/01, 2001).
\end{abstract}

The possibility of access to jurisdiction by individuals is protected by article 116 of the Political Constitution of Colombia, which grants them temporary jurisdiction as conciliators or arbitrators authorized by the parties, with the aim of conferring the same effects as a court decision, through a conciliation act or an arbitration decision issued by an arbitration tribunal. In this regard, the Constitutional Court has stated that:

(...) in accordance with the Court's case law, access to justice implies not only the possibility for any person to request the protection of their rights before the competent judges, but also, by express authorization of article 116 of the Constitution, to have their disputes resolved through mechanisms such as conciliation or arbitration (Colombian Constitutional Court, Full Chamber, D-3638 - C-314/02, 2002).

Jurisdictional investment for conciliators and arbitrators is transitory and for the purposes of conciliation. Whoever holds this prerogative must use his responsibility, not to issue a ruling that resolves the dispute, but to provide tools to the parties in conflict that, in their autonomy, will seek a peaceful solution to the problematic circumstance (Osna, 2019). The establishment of conciliation as a requirement of procedence presents a dilemma as to whether it is understood as an opportunity for the peaceful resolution of disputes or simply as an extension of judicial processes. In fact, citizens confuse the summons to appear at the conciliation hearing with a notice of legal action. Therefore, conciliation is not being understood as an opportunity to solve an existing conflict in a satisfactory manner without decongesting the judicial system. 
Furthermore, some authors have criticized the fact that conciliation is a necessary procedural requirement for access to judges, as this requirement is understood as a distortion of the very purpose of conciliation (Meza et al,, 2018). However, this fact implies the intention to give the opportunity for the conflict to be solved among those directly concerned and not by an outsider.

With regard to the internal order of the Russian Federation, the Constitution of the Russian Federation (1993) in its preamble reaffirms the incorporation of human rights as a fundamental norm in the following manner:

We, the multinational people of the Russian Federation, united by a common fate on our land, establishing human rights and freedoms, civic peace and accord, preserving the historically established state unity, proceeding from the universally recognized principles of equality and self-determination of peoples, revering the memory of ancestors who have conveyed to us the love for the Fatherland, belief in the good and justice, reviving the sovereign statehood of Russia and asserting the firmness of its democratic basic, striving to ensure the well-being and prosperity of Russia, proceeding from the responsibility for our Fatherland before the present and future generations, recognizing ourselves as part of the world community, adopt the CONSTITUTION OF THE RUSSIAN FEDERATION.

Furthermore, some authors have criticized the fact that conciliation is a necessary procedural requirement for access to judges, as this requirement is understood as a distortion of the very purpose of conciliation (Meza et al,, 2018). However, this fact implies the intention to give the opportunity for the conflict to be solved among those directly concerned and not by an outsider.

With regard to the connection between individuals and the administration of justice, the Russian Constitution states the following:

1. Citizens of the Russian Federation shall have the right to participate in managing state affairs both directly and through their representatives. 2. Citizens of the Russian Federation shall have the right to elect and be elected to state bodies of power and local self-government bodies, and also to participate in referenda. 3. Deprived of the right to elect and be elected shall be citizens recognized by court as legally unfit, as well as citizens kept in places of confinement by a court sentence. 4. Citizens of the Russian Federation shall enjoy equal access to the state service. 5. Citizens of the expenditures shall have the right to participate in administering justice (Constitution of the Russian Federation, 1993, art. 32).

Unlike the Colombian Constitution, the Russian Constitution does not establish the possibility of access to jurisdiction through individuals, understood as the function of doing justice. This can be seen in the first paragraph of Article 118 of the Constitution. There it is established that justice can only be administered in the Russian Federation by courts established in accordance with the law.

\section{II. The emergence of conciliation in Colombia and mediation in Russia}

Conciliation in Colombia first appeared in labor law, specifically in Decree 2158 of 1948, which was taken as a permanent rule by Decree 4133 of 1948, the Code of Labor Procedure, which in its article 19 allowed conciliation at any time, before or after the lawsuit was filed. Through Law 23 of 1991, an attempt was made to regulate labor legislation; however, this legislation never came into force, because the decree allowing the Ministry of Labor and Social Security to make the amendments for due execution was not issued. Later, 
article 31 of Decree 2303 of 1989, concerning agrarian proceedings, provided that in ordinary proceedings especially demarcation and boundary marking - there would be a preliminary conciliation hearing, as in all declarative proceedings of an agrarian nature, in accordance with article 35 of the same regulation. It is also important to mention Article 101 of Decree 2282 of 1989. This introduced judicial conciliation hearings, which not only opened up the possibility of holding them in ordinary proceedings, but also included consequences for the non-attendance of the parties. Some of these consequences were serious indications against the claims or exceptions of merit as the case may be, as well as fines of 5 to 10 monthly minimum wages for the reluctant party.

With regard to civil law, article 64 of Law 446 of 1998 defined conciliation as an alternative dispute resolution mechanism, highlighting the role of the conciliator as a neutral and qualified third party, as well as emphasizing that the solution to the conflict arises from the management of the parties themselves. In particular, article 101 of Law 446 of 1998, which was repealed by article 49 of Law 640 of 2001, gave the opportunity to hold the judicial conciliation hearing in proceedings in which no first or single instance ruling had been issued, and which dealt with matters susceptible to conciliation. Something similar was determined for the executive processes, in light of the fact that conciliation was required as a prerequisite whenever the defendant had raised objections on merit. It is worth mentioning that the above-mentioned procedural diligence was in turn repealed by Article 69 of Law 794 of 2003.

González (1999), in the explanatory memorandum of Law 640 of 2001, highlights the importance of strengthening alternative justice, which was developed in Law 446 of 1998 as a form of peaceful resolution of disputes. The author mentions that this law will allow Colombians to be "better neighbors, (...) and, therefore, men and women of peace, who will know how to sow seeds of hope and travel paths of understanding". In a similar sense, Castillo (2012) states that conciliation also has an ethical function, since it allows the construction of a culture of peace.

Law 1564 of 2012, known as the General Procedural Code, also included extrajudicial conciliation, considering it a cause of inadmissibility of a lawsuit. It should be clarified that in this law, extrajudicial conciliation has a different role from that established in article 36 of Law 640 of 2001, which had typified it as a cause for rejection in limine. However, since the General Procedural Code is a later standard, it is currently applicable as a ground for inadmissibility, even more so when the aim is to protect the claimant's access to justice, when proof of the exhaustion of this requirement has been omitted due to simple negligence or oversight.

The Ten Year Plan for the Justice System, adopted with Decree 979 of 9 June 2017 of the Colombian Ministry of Justice and Law, instituted conciliation as an alternative method of conflict resolution, which is related to the implementation of conciliation in the territories that have historically had a presence of the actors of the Colombian conflict.

Mediation in Russia has a peculiar history. Historically it has been used throughout the Russian nation in the framework of restorative justice. This is understood as a mechanism of response to criminal behaviour by balancing the needs of the community, the victims and the offenders. Restorative justice is an evolving concept that has generated various interpretations in different countries, on which there is not always consensus. However, in Russia it has been established in the past with a purely community approach to enable the community to deal with crime, its effects and ways of preventing it. The system applied in Russia was based on the Canadian model of restorative mediation, in which so-called "restorative mediators" seek to involve the offender in the victim's reparation. The principles guiding restorative justice in Russia were as follows: 1. Reaffirmation of the role of the victim in the pursuit of justice. 2. Rehabilitation and reintegration as opposed to retribution and punishment. 3. Reduction of imprisonment rates (Dünkel et al., 2015). 
Federal Law N 193-FZ of 2010 regulated some procedures on alternative methods of conflict resolution. In 2011, the Russian Duma implemented the above-mentioned federal legislation through which a mediation program was established for the resolution of civil disputes, including matters of an economic, labor and family nature. It should be noted that, although the law is called "Procedures of alternative methods of conflict resolution", it focuses exclusively on the figure of mediation, the role to be played by the mediator and certain procedures regulating the relations that arise between the parties during mediation.

The legislation implemented in 2011 was designed to establish and promote the use of mediation as a self-policing mechanism in a variety of civil and commercial activities throughout the country. The main purpose of the legislation is to promote the harmonization of social relations. Another important part of the law provides for the obligations of the mediator, including compliance with strict ethical standards. It also sets out the obligations and guidelines to be followed by organizations offering mediation services. These organizations are also responsible for keeping a strict Register of Mediators.

\section{Conciliation as a self-composition instrument to resolve conflicts in Colombia}

The Political Constitution of Colombia, in its article 116, allowed individuals to be invested with jurisdiction on a transitory basis in their capacity as arbitrators and conciliators. This article states:

Article 116. The Constitutional Court, the Supreme Court of Justice, the Council of State, the Superior Council of the Judicature, the Office of the General Prosecutor (Fiscalía General de la Nación), the courts, and judges all administer justice. The military criminal justice system also administers justice. The Congress will exercise specific judicial functions. Exceptionally, the law may assign jurisdiction of specific subject areas to specified administrative authorities. However, they will not be allowed to hold hearings of civil law proceedings nor penal proceedings. Individuals may be invested on a temporary basis with the function of administering justice as mediators or as qualified arbitrators by the parties involved to hand down verdicts whether at law or in equity, within the limits determined by law (art. 116, Political Constitution of Colombia, 1991).

By relating the content of the above-mentioned article to the constitutional right of access to justice developed in articles 228 and 229, it can be inferred that the concept of administration of justice is not limited to the intervention of judges of the Republic as agents of the State. On the contrary, justice is also deprecated on individuals when they provide the transitional jurisdictional service that empowers them to act in conciliation. In this sense, the parties to the conflict, as citizens, are empowered to manage and resolve the dispute by consensus and with the aim of obtaining a fair settlement. Azula (2016) states that the legislator's main reason for instituting conciliation was to avoid the respective contentious process and the consequences it entails.

In this regard, the Constitutional Court, in Ruling C-1195 of November 15, 2001, stated

According to the Court's case law, access to justice implies not only the possibility for any person to request the protection of his or her rights before the competent judges, but also, by express authorization of article 116 of the Constitution, the possibility to resolve his or her disputes through mechanisms such as conciliation or arbitration (Corte Constitucional de Colombia, Full Chamber, D-3519 - C-1195/01, 2001).

Law 640 of 2001 conditioned the temporality of the investiture of the jurisdiction of the conciliator to 
a term of three months. By "temporality", it refers to the maximum time granted to the individual so that he can carry out actions in accordance with the constitutionally authorized investiture, which begins from the moment the individual is assigned as conciliator. The Constitutional Court, in Ruling C-893/01, states:

\begin{abstract}
This faculty is essentially occasional or transitory and is also voluntary or spontaneous in nature, since the parties are the ones who empower the individual to resolve his or her dispute. The transitory and alternative nature of these instruments derives from the fact that they constitute a form of collaboration by individuals for the good success of the administration of justice (Corte Constitucional de Colombia, Full Chamber, D-3399 C-893/01, 2001).
\end{abstract}

With regard to the agreements that can be established, according to Tamayo (2003), "most Latin American country codes, due to the influence of the French code, have adopted the classic classification: contracts, quasi-contracts, offences, quasi-felonies and law" (p. 32). With respect to the above, the benefits that are mutually agreed upon in a conciliation act come from a consensual source of obligations protected by the law and the Political Constitution of Colombia; therefore, the conciliation act has executive merit and becomes res judicata (Arrieta \& Meza, 2019). It should be noted that the judicial powers of decision and coercion that apply to the judges of the Republic are not possessed by the conciliator, since the latter is an impartial third party who mediates by consensus between the parties, and the conciliator is not allowed to issue rulings that end disputes arising from declaratory, constitutional or sentence claims. However, the conciliator is vested with the power of validation, which he exercises once the litigious matter has been discussed at the hearing and, consequently, an agreement between the parties has materialized.

Law 446 of 1998, in its article 64, defined conciliation as "a conflict resolution mechanism through which two or more persons manage the solution of their differences by themselves, with the help of a neutral and qualified third party, called a conciliator". On the other hand, the Constitutional Court in its Ruling C-1195 of November 15, 2001, stated that the term conciliation has two different meanings depending on the context in which it is used: one procedural and one substantial. In relation to its procedural meaning, conciliation is "a mechanism for resolving disputes through which two or more persons manage the resolution of their differences by themselves, with the help of a neutral and qualified third party, called a conciliator".

Law 446 of 1998, in its article 64, defined conciliation as "a conflict resolution mechanism through which two or more persons manage the solution of their differences by themselves, with the help of a neutral and qualified third party, called a conciliator". On the other hand, the Constitutional Court in its Ruling C-1195 of November 15, 2001, stated that the term conciliation has two different meanings depending on the context in which it is used: one procedural and one substantial. With regard to its procedural meaning, the Constitutional Court offered a definition very similar to that used in article 64.

According to the above definition, and in accordance with the Technical Concept of the Ministerio del Trabajo de Colombia (2018), conciliation institutes a succession of predisposed phases that have as an eventual, but not compulsory, object an agreement between two or more persons. However, the word conciliation also refers to the "agreement reached by the conclusion of the conciliation procedure. In this second substantive sense, conciliation takes the form of a record of the agreement reached by the parties, certified by the conciliator". (Ministerio del Trabajo de Colombia, Technical Concept 3970, 2018).

Azula (2016) defined conciliation as an act carried out by the parties in dispute, with the intervention of a third party, which seeks to end a process (or avoid a future one) by means of total or partial agreement on what is in dispute. Cuesta-Cuesta (2015) defined it more precisely, since the author specified that it is a figure with constitutional and legal rank through which the parties, with the collaboration of an impartial 
and neutral third party called a conciliator, seek the solution to a conflict that is waivable, transgestible, as long as it is not prohibited by law to carry out such a procedure. It has the effect of providing executive merit, making it res judicata and suspending the term of prescription and expiry. Tamez et al. (2018), on the other hand, specify that "conciliators do not interpret the law or the rules, but it is up to them to weigh and balance the conflicting interests of the parties, which means that their results do not have the decisive character of a judgment" (p. 391). Arboleda et al. (2018) clarify that conciliation is not a way to decongest justice, since its importance is much broader than just being a means of decongestion, since it generates social fabric, dialogue and the positioning of agreements as the intelligent way to resolve conflicts. For this reason, conciliation is a new way of doing justice.

Conciliation is therefore considered to be a method of citizen self-composition rather than just an alternative and/or complementary method of conflict resolution. This implies that it promotes peaceful coexistence and fair order by fostering negotiated agreements between the citizens on their disputes with the intervention of an impartial third party called a conciliator invested with jurisdiction on a transitory basis.

\section{Special characteristics of conciliation in Colombia}

Constitutional Court Ruling C-893 of August 22, 2001 developed the characteristics of conciliation, which are set out in the following considerations:

- By definition, conciliation is a voluntary, private and bilateral system of conflict resolution

The benefits arising from the conciliation agreement have a consensual and legal source not linked to the conciliator. The conciliator is limited to proposing possible settlement solutions and endorsing what has been agreed by the parties. This agreement, once recorded in a document, will be enforceable and will become a material or formal final decision, depending on the case that can be conciliated. Thus, the conciliator will seek to ensure that what has been agreed has clear circumstances of manner, time and place, so that, in the event of non-compliance, the act will provide executive merit, as it contains the requirements of Article 422 of the General Process Code - CPG. In other words, it must consist of a clear, express and enforceable title and therefore the creditor of the right need only initiate the relevant enforcement action.

- Conciliation can take place in the course of court proceedings or outside them

Article 3 of Act No. 640 of 2001 classifies conciliation in a) judicial; b) extra-judicial, and c) in law and in equity; each of these concepts will be developed below.

$\gg$ Judicial conciliation: This is carried out during the judicial process, which is explicitly found in the initial hearing of the verbal process or in the single hearing of the summary verbal process. It may also be requested by the parties in the process or promoted by the judge when he observes the intention of the parties to reach an agreement. In the latter case, the judge may order it on the basis of article 43 of Act No. 640 of 2001, which allows the hearing to be held at any stage of the proceedings.

$\gg$ Extra-judicial conciliation: This is carried out outside the process, provided that it is done in accordance with the guidelines set out in Law 640 of 2001 and before a conciliator authorized for the purpose. Rojas (2013) defined it as that which takes place outside the judicial process, whether it is done before a judge who acts as a conciliator or before another public or private authority authorized by law.

$\gg$ Conciliation in law and in equity: Regarding the difference between conciliation in law and conciliation in equity, Pallares (2003) states that in some way the difference is reduced to the technique. This 
is because, frequently, the former requires the use of equity criteria for the solution, while the latter, in order not to incur in arbitrariness, takes advantage of strictly legal techniques.

Azula (2016) explains the difference between conciliation in law and conciliation in equity as follows: a) It is in law when the agreement is based on what is enshrined in the positive law. b) It is in equity if the agreement is obtained regardless of what is enshrined in the rule on the subject matter of the dispute or difference and is based on conscience. It should be stressed that justice in equity should not operate against public order or morality, so that conciliation in equity cannot be deduced from an arbitrary and illegal agreement. However, a sense of breadth does exist in that it seeks to restore fair order between the parties without implying a specific application of the legal rule, as is expected from conciliation in law. In the latter, the conciliator is required to be a lawyer qualified to conciliate.

Law 446 of 1998, in articles 106-110, grants conciliation acts in equity the same effects as conciliation acts in law: the granting of executive merit and the making of a transition to res judicata. Article 3 of Law 640 of 2001 requires that conciliation in law be done before conciliation centres or before authorities in the performance of their conciliation functions, while conciliation in equity is done before conciliators in equity, which leads to the conclusion that in both cases the procedural requirement expressed in articles 35 and 38 of Law 640 of 2001 may be exhausted.

- The role of the conciliator is to administrate justice in a transitory manner and the conciliation as a jurisdictional act

There is a three-month term for the extra-judicial conciliation hearing, established in article 20 of Law 640 of 2001. However, judicial conciliation may be promoted by the judge of knowledge at any stage of the process before issuing a sentence, when he considers that the parties are in a spirit of agreement. Conciliation acts are enforceable and become res judicata, that is, they have the same effect as a judgment.

- Conciliation is an exceptional mechanism

There are cases in which it is not necessary to exhaust the procedural requirement of articles 35 and 36 of Law 640 of 2001, which are determined below:

$\gg$ When, under the seriousness of the oath, which is deemed to have been taken when the lawsuit is filed, it is shown that the domicile, place of residence and place of work of the defendant is unknown, or that the defendant is absent and his whereabouts are unknown.

$\gg$ When in the process it is intended to request the decree and the practice of precautionary measures, it is possible to go directly to the ordinary jurisdiction.

$\gg$ In expropriation and divisional processes.

$\Rightarrow$ In proceedings with executive or settlement claims.

$\gg$ In family proceedings where there are circumstances of domestic violence. This ground was set out in Ruling C-1195 of 2001 of the Constitutional Court, under the concept of protection of the victim, in order not to force her to meet her aggressor again.

$\gg$ In other cases, as determined by law, such as in the process of restitution of possession.

With regard to the application for precautionary measures, it should be made clear that the procedural requirement is excluded when the application is merely made. Consequently, if the measure is requested and for some reason it is not granted, the process would not be invalidated for violation of due process. 
To close this section, it is important to stress the importance of the role of conciliation as a mechanism for peaceful and self-compulsory solutions, since the mere fact that the procedural requirement does not have to be met for a case does not mean that conciliation cannot be triggered. An example of this is the process of restitution of leased property in which the rule of the General Procedural Code expressly exempts the exhaustion of this requirement for the filing of the suit. However, if we bring up article 69 of Act 446 of 1998, we see that restitution can be made if an agreement to surrender is reached at a conciliation hearing and, even so, the tenant refrains from surrendering the property in the manner, time and place agreed in the minutes. In other words, if the claim is only for restitution, a simple agreement would avoid the proceedings before the judicial authorities to achieve the same end, in addition to exempting it from greater costs arising from the expenses of a legal action.

\section{Mediation in Russia and the establishment of mediation law}

The mechanism of mediation has become a legitimate method of resolving legal disputes. However, it has not succeeded in replacing existing jurisdictional institutions (court procedure or dispute resolution in the arbitration court). Even so, it coexists harmoniously with these and offers new opportunities for the peaceful resolution of conflicts. For more than two decades, Russia has maintained an open economy, as well as exercised trade with some success within the regulations of its Civil Code. In this relatively short period of time, Dispute Resolution Mechanisms (DSM) have not played a significant role in resolving legal problems. Except for the arbitration of contractual stipulations, foreign investors have historically preferred to resolve their disputes through this heterocomposite mechanism, rather than the ordinary Russian justice system. In other words, foreign companies have shown a certain distrust of the jurisdictional branch of the Russian Federation as a means of resolving disputes associated with Russian companies (Baker McKenzie, 2013).

The Federal Law on Dispute Settlement Mechanisms (Mediation Law) has established a procedure for the resolution of disputes involving a mediator on the basis of the voluntary consent of the parties. The mediation mechanism has applicability in civil disputes (which includes disputes over economic relations), labour disputes (except collective labour law disputes) and family law disputes. However, it is not possible for the mediation mechanism to take place in the above-mentioned disputes if public interests or rights are affected (Davydenko, 2012). Nor will it take place if the legitimate interests of third parties who are not involved in the mediation procedure have not been convened.

Unlike Colombia, Russia has not instituted any dispute settlement mechanism as a procedural requirement that must be exhausted in advance for the interested party to have access to ordinary jurisdiction. The Law on Mediation regulates the use of this mechanism in disputes arising from civil and commercial relations, which includes intellectual property disputes involving both industrial property and copyright, as well as conflicts in the area of labor and family relations.

\section{Mediation as a self-composition instrument in Russia}

With regard to the time frame of the mediation, the parties have the power to choose this self-composition mechanism prior to the start of the judicial proceedings or having initiated a judicial process. The parties can use mediation even before a decision on the merits of the case is made. In the latter case, the judge could approve the mediation agreement which would put an end to the dispute. Unlike conciliation in Colombia, 
the legal nature of the act of mediation is contractual; the law recognizes the mediation agreement as a civil contract that constitutes an executive title.

Federal Law N 193-FZ of 2010 prohibits the parties from going to the ordinary jurisdiction or to the arbitration court once the mediation has been concluded through an agreement between the parties. However, if a complaint has been filed with the courts or the arbitration court, the parties are free to use the mediation mechanism at any time before the courts described above settle the matter of substance (Korovyakovsky, 2014). The law also stipulates that information disclosed by the parties during the mediation procedure must be kept confidential. Thus, neither the mediator nor the parties may disclose or use such information in other spaces, unless the parties agree otherwise.

The proposal for mediation in Russia starts with a written request submitted by one party to the other, if no response is received within 30 working days the proposal will be considered rejected. If an agreement is reached, it must identify the object of the mediation, the name of the institution providing the services or, failing that, the name of the mediators. Likewise, the agreement must detail the services to which the parties are obliged and the terms on which expenses, if any, must be incurred. By mutual agreement, the parties may select the mediator - or mediators - from the list of registered mediators, ask the institution providing mediation services to recommend a mediator or ask that organization to appoint one (Bryzhinskaya \& Hudoykina, 2015). Once the appointment has been made, the mediator should inform the parties, or the institution that appointed him/her, if his/her independence or impartiality is compromised due to relationship with any of the parties, kinship or common business.

With regard to the remuneration of the mediator, Russian law provides that the mediator is free to charge a fee for his services; however, costs incurred by the mediator or the institution offering the mediation should be compensated by the parties equally unless otherwise agreed. The mediator, unless expressly requested by the parties, may not offer settlement formulas to resolve the dispute, but may hold separate or joint meetings with the parties before and during the mediation process.

\section{Special elements of mediation in Russia}

The agreement between the parties concluding the dispute must be in writing, identify each of the parties, the mediator(s), the subject matter of the dispute, the terms of the agreement and the time limits agreed by the parties, and must also be materialized within a maximum of sixty calendar days, unless the parties decide to extend it. In this case, the term to implement the mediation procedures should not exceed one hundred and eighty calendar days. If the dispute arose as a result of the court action or arbitration, the time for implementation should not exceed sixty days (Hudoykina, 2015).

By virtue of the preponderant prohibitions that the law establishes for the mediator, he or she may not represent the parties, offer legal advice or consultancy, participate in private business directly or indirectly with those involved, interact with the press, or make public announcements about the object of the dispute without the express consent of the parties. In order to be able to mediate, one must be 25 years of age, be a professional (i.e., have a degree from a higher education institution) and have completed a course on mediation in accordance with the law. 


\section{Final considerations}

Access to justice is a human right that has been positivized as a fundamental right in the constitutions of Colombia and Russia; however, the Constitution of Colombia allows the function of jurisdiction to individuals on a transitory basis, unlike the Russian Constitution which only empowers judges of the Federation to exercise jurisdictional functions. Mediation as a method of conflict resolution is a real instrument that facilitates access to justice, without the need for the intervention of a judge who determines the dispute by exercising his or her decision-making power. However, the Russian experience in the implementation of alternative justice is still small, the mechanism of mediation has had a gradual impact or acceptance in Russian society.

In both States, the implementation of alternative dispute resolution mechanisms has been prompted by the need to relieve the burden on courts and tribunals of ordinary justice. Both States have a rather litigious tradition centered on ordinary justice, so it is imperative to insist on the mass use of these instruments that make possible a justice that comes from the parties in conflict, which implies the power to repair relations, which could contribute to a more peaceful society.

The mediator in Russia does not have transitional jurisdictional powers, but simply seeks a peaceful and harmonious environment for the resolution of the dispute. In Colombia, the conciliator endorses the decision of the parties with his signature, which gives the conciliation act the same effect as a court order. In Colombia, the very nature of the conciliator empowers him to offer settlement formulas and meet separately with the parties, so that he can favour the achievement of the resolution of the conflict. However, mediation in Russia only provides this power in the mediator if the parties previously agree that he can provide settlement formulas. In this sense, it can be observed that the Colombian conciliation offers more guarantees for the resolution of the conflict.

As a meeting point between the two instruments, in the event that a solution to the dispute is found, the final document gives executive merit. However, the nature of both documents is different: in Colombia, the conciliation act has the same effects as a court judgment, while in Russia it is merely contractual.

An interesting point provided for in the Federal Law N 193-FZ of 2010 is that the mediator can hold any kind of formal profession resulting from university education. In Colombia, the possibility to practice conciliation is only granted to qualified lawyers with a valid professional card. In both cases, specialized courses must be taken in order to practice the profession of conciliation and mediation.

The figure of the conciliation is much more robust than the figure of the mediator. Similarly, Colombian law offers many more guarantees for the amicable settlement of the conflict by empowering the conciliator as an impartial third party, but who intervenes by seeking formulas for settlement. It would be highly advisable for Russian legislators to be familiar with Colombian legislation on alternative dispute resolution mechanisms so that they can refine the Russian Federation's alternative methods of justice. 


\section{Bibliographic references}

Arboleda, A., Ramírez, C., Mancipe, G. Garcés, L. \& Arboleda, S. (2018). La conciliación virtual extrajudicial en Derecho; reflexiones frente a la ética. Justicia, 24(34), 372-384. DOI: https://doi.org/10.17081/ just.23.34.2897

Arrieta, M., \& Meza, A. (2019). Efectividad de la función de concreción de la obligación alimentaria de los defensores de familia en la ciudad de Barranquilla entre los años 2015 y 2017. Revista Jurídicas, 16(2), 147-165. DOI: 10.17151/jurid.2019.16.2.10

Arrieta-López, M. (2020). From Peace and The Planetary Republics of the Century of Lights to the Materialization of Perpetual Peace and Universal Citizenship. / De la paz y las repúblicas planetarias del siglo de las luces a la materialización de la paz perpetua y la ciudadanía universal. Utopía y Praxis Latinoamericana, 25, 473-488. DOI: http://doi.org/10.5281/zenodo.4278408 Recuperado de https:// produccioncientificaluz.org/index.php/utopia/article/view/34534

Arrieta-López, M. (2019). De la democracia a la Aretecracia: origen, evolución y universalización / From Democracy to the Aretecracia: Origin, Evolution and Universalization. Utopía y Praxis Latinoamericana, 24, 115-132. Retrieved from: https://produccioncientificaluz.org/index.php/utopia/article/view/29689

Arrieta López, M. (2018). La Aretedemocracia o Virtudemocracia: Un sistema de gobierno calificado contra las deformaciones de la democracia / Aretedemocracy or Virtuedemocracy: A system of qualified government against deformations of democracy. Justicia, 23(34), 539-554. https://doi.org/10.17081/ just.23.34.3406

Asamblea Nacional Constituyente de Colombia. (1991). Constitución Política de Colombia. [Const]. Retrieved from: http://www.suin-juriscol.gov.co/viewDocument.asp?ruta=Constitucion/1687988

Azula, J. (2016). Manual de derecho procesal [Tomo I]. Bogotá, Colombia: Editorial Temis.

Baker Mckenzie. (2013). Dispute Resolution around the World. Russia. Retrieved from: https://www. bakermckenzie.com/-/media/files/insight/publications/2016/10/dratw/dratw_russia_2013. pdf?la=en

Bonta, B. (1996). Conflict Resolution among Peaceful Societies: The Culture of Peacefulness. Journal of Peace Research, 33(4), 403-420.

Brandt, H.-J. (2017). La justicia comunitaria y la lucha por una ley de coordinación de la justicia. Derecho PUCP, (78), 215-247. https://doi.org/10.18800/derechopucp.201701.009

Bryzhinskaya, G., \& Hudoykina, T. (2015). The negotiation process: Psychological and legal analysis. Paradigmata Poznani, 1, 65-67.

Castillo, C. (2012). La conciliación extrajudicial y la necesidad de su rango constitucional. Pontificia Universidad Católica del Perú. Retrieved from: http://blog.pucp.edu.pe/blog/ conciliacionyarbitrajepatmos/2012/03/06/la-conciliacion-extrajudicial-y-la-necesidad-de-surango-constitucional/

Congreso de la República de Colombia. 12 de julio de 2012. Por medio de la cual se expide el Código General del Proceso y se dictan otras disposiciones. Ley 1564 de 2012. DO: 48489.

Congreso de la República de Colombia. 5 de enero de 2001. Por la cual se modifican normas relativas a la conciliación y se dictan otras disposiciones. Ley 640 de 2001. DO: 44.303. 
Congreso de la República de Colombia. 7 de julio de 1998. Por la cual se adoptan como legislación permanente algunas normas del Decreto 2651 de 1991, se modifican algunas del Código de Procedimiento Civil, se derogan otras de la Ley 23 de 1991 y del Decreto 2279 de 1989, se modifican y expiden normas del Código Contencioso Administrativo y se dictan otras disposiciones sobre descongestión, eficiencia y acceso a la justicia. Ley 446 de 1998. DO: 43.335.

Congreso de la República de Colombia. 8 de enero de 2003. Por la cual se modifica el Código de Procedimiento Civil, se regula el proceso ejecutivo y se dictan otras disposiciones. Ley 794 de 2003. DO: 45058.

Corte Constitucional de Colombia, Sala plena. (15 de noviembre de 2001). Sentencia C-1195. Exp. D-3519. [MP Manuel José Cepeda Espinoza \& Marco Gerardo Monroy Cabra].

Corte Constitucional de Colombia. Sala plena. (22 de agosto de 2001). Sentencia C-893. Exp: D-3399. [MP Clara Inés Vargas Hernández].

Corte Constitucional de Colombia. Sala plena. (30 de abril de 2002). Sentencia C-314. Exp. D-3638. [MP Marco Gerardo Monroy Cabra].

Cuesta-Cuesta, D. (2015). La conciliación en el ordenamiento jurídico colombiano. Una nueva forma de enseñar Derecho. Bogotá: Ediciones Universidad Cooperativa de Colombia. DOI: https://doi.org/10.16925/ greylit.1443

Davydenko, D. (2012). Practice of commercial mediation in Russia: Some examples and problems. Theory and practice of commercial mediation. In: V. Zagaynova (ed.), Collection of Articles (190-213). Moscow: Infotropik Media.

Dünkel, F., Horsfield, P., \& Parosanu, A. (2015). Research and Selection of the Most Effective Juvenile Restorative Justice Practices in Europe: Snapshots from 28 EU Member States. International Juvenile Justice Observatory. Retrieved from: https://www.oijj.org/en/docs/publications/research-andselection-of-the-most-effective-juvenile-restorative-justice-practice

González, R. (1999). Exposición de motivos Ley 640 de 2001. Ministro de Justicia y del Derecho. Senado de la República, Secretaría General.

Hudoykina, T. (2015). Current Status and the Development Prospects of Mediation in Russia as an Alternative Means for the Settlement of Economic Disputes. International Journal of Economics and Financial Issues, 5(35), 224-230.

Korovyakovsky, D. (2014). The procedure of mediation in Russia and in the United Kingdom: A comparative legal characteristic. Russian Judge, 12, 23-25.

Meléndez, Y., Paternina, J., \& Velásquez, D. (2018). Procesos de paz en Colombia: derechos humanos y familias víctimas del conflicto armado / Peace processes in Colombia: human rights and victim families of the armed conflict. JURIDICAS CUC, 14(1), 55-74. https://doi.org/10.17981/juridcuc.14.1.2018.03

Meza, A., Arrieta, M., \& Noli, S. (2018). Análisis de la conciliación extrajudicial civil en la Costa Atlántica colombiana / Analysis of civil extrajudicial conciliation in the Colombian Atlantic Coast JURIDDICAS CUC, 14(1), 187-210. DOI: http://dx.doi.org/10.17981/juridcuc.14.1.2018.9

Ministerio de Justicia y del Derecho de Colombia. (2016). Resolución 018.

Ministerio de Justicia y del Derecho de Colombia. (9 de junio de 2017). Por el cual se adiciona el Capítulo 13 al Título 3 de la Parte 2 del Libro 2 del Decreto 1069 de 2015, Decreto Único Reglamentario del Sector Justicia y se adopta el Plan Decenal del Sistema de Justicia 2017-2027. [Decreto 979]. DO: 50259.

Ministerio del Trabajo de Colombia. (2018). Efectos de la audiencia de Conciliación celebrada ante el Ministerio de Trabajo. Concepto Técnico 3970. 
Noli, S., Arrieta, M., \& Meza, A. (2018). Perspectivas sobre la concertación de un convenio bilateral integral entre China y Colombia / Perspectives on the concertation of a bilateral integral agreement between China and Colombia. Revista Espacios, 39(42), 24. Retrieved from: http://www.revistaespacios.com/ a18v39n42/18394224.html

Osna, G. (2019). Acceso a la justicia, cultura y online dispute resolution. Derecho PUCP, (83), 9-27. https://doi. org/10.18800/derechopucp.201902.001

Pallares, J. (2003). Arbitraje, Conciliación y Resolución de Conflictos. Bogotá, Colombia: Editorial Leyer.

Rojas, M. (2013). Lecciones de derecho Procesal. Bogotá, Colombia: Editorial ESAJU.

Russian Federation. Constitutional Comission. (1993). Constitution of the Russian Federation. Retrieved from: https://www.constituteproject.org/constitution/Russia_2014.pdf?lang=es

Russian Federation. Federal Assembly. Federal Law N 193-FZ, 27 july 2010, Alternative Dispute Resolution Mechanisms. Collection of Laws of the Russian Federation No. 31.

Tamayo, A. (2004). Manual de obligaciones. Bogotá, Colombia: Editorial Temis.

Tamez, G., Montalvo, D., Leyva, O. \& Hernández, A. (2018). Análisis comparativo sobre los métodos alternativos para la resolución de conflictos a partir de la legislación de los Estados de la República Mexicana. Justicia, 24(34), 385-404. DOI: https://doi.org/10.17081/just.23.34.2899

United Nations General Assembly. (1948). Universal declaration of human rights (217 [III] A). Paris. Retrieved from: http://www.un.org/en/universal-declaration-human-rights/ 